\title{
DNA BARCODING OF ENDANGERED GIANT CLAMS IN ISLANDS OFF THE EAST COAST OF PENINSULAR MALAYSIA
}

\author{
NUR SYAHIRAH MAMAT ${ }^{1}$, YUSRI YUSUF ${ }^{2}$, SITI AZIZAH MD NOR ${ }^{3}$, SHAHREZA MD \\ SHERIFF $^{4}$, MD NIZAM ISMAIL $^{5}$ AND NORAINY MOHD HUSIN ${ }^{1 *}$ \\ ${ }^{1}$ Institute of Tropical Aquaculture and Fisheries (AKUATROP), ${ }^{2}$ Faculty of Marine Science and Environment, ${ }^{3}$ Institute \\ of Marine Biotechnology, ${ }^{4}$ Faculty of Fishery and Food Sciences, Universiti Malaysia Terengganu, 21030 Kuala Nerus, \\ Terengganu, Malaysia. ${ }^{5}$ Fisheries Research Institute (FRI) Batu Maung, Department of Fisheries Malaysia, Ministry of \\ Agriculture \& Food Industry, 11960 Batu Maung, Penang.
}

*Corresponding author: norainyhusin@umt.edu.my

Submitted final draft: 2 September 2020 Accepted: 10 September 2020

http://doi.org/10.46754/jssm.2021.07.003

\begin{abstract}
This study reports on the taxonomic verification and distribution of three presumed morphologically identical Tridacna species (giant clams), namely $T$. crocea, T. maxima and T. squamosa, from nine localities in islands off Terengganu, Pahang and Johor in the east coast of Peninsular Malaysia. A 467-bp partial sequence of mitochondrial DNA cytochrome c oxidase 1 (MT-CO1), which serves as the DNA barcoding gene, was analysed for species identification of 247 samples. The MT-CO1 gene was successfully used to identify all the giant clam samples to species level based on GenBank BLAST and BOLD databases. Three highly-supported clusters were obtained, which supported the morphological species determination into T. crocea, T. maxima and T. squamosa. However, a few discrepancies were observed, which could be attributed to misidentification of juveniles. T. squamosa and T. crocea were more closely related to each other compared to T. maxima. T. maxima and T. squamosa were found to be ubiquitous in all the islands, while $T$. crocea was restricted to the southeastern islands of Pahang and Johor. The precise identification of samples through the MT-CO1 gene and information on their distributions are useful in strategising the conservation and management of giant clams in this region.
\end{abstract}

Keywords: DNA barcoding, mtDNA, giant clams, Tridacna, conservation.

\section{Introduction}

Correct identification of species is a prerequisite for conserving and protecting endangered organisms. The giant clam is the largest group of bivalve molluses belonging to the genera Tridacna and Hippopus. Like other marine bivalves, they have a photosynthetic symbiosis with the zooxanthellae algae of the Symbiodiniaceae family for nutritional requirements (Morishima et al., 2019). The size of adult clams ranges from $15 \mathrm{~cm}$ in the smallest $T$. crocea, to $1.5 \mathrm{~m}$ in $T$. gigas, the largest species (Hui et al., 2016). However, its striking features have exposed it to varied forms of exploitation. The clams have been overharvested for food, tile manufacturing (shells), the aquarium trade and production of souvenirs (Kochzius \& Nuryanto, 2008; Heslinga, 2013). As such, its opulation has reduced throughout its geographic range (Mohammed et al., 2019). Most giant clam species, including $T$. crocea, T. maxima and T. squamosa, are listed in the Convention on International Trade in Endangered Species of Wild Fauna and Flora (CITES) (Appendix II), where sales of the species and its products are supposed to be strictly regulated. The three giant clams may be found in the three major groups of islands off Johor, Pahang and Terengganu in the east coast of Peninsular Malaysia (Neo et al., 2017).

The classification of giant clams has traditionally been based on shell morphology and mantle characteristics. While the morphological approach is the basis of taxonomic identification, it has limitations and sometimes may lead to erroneous conclusions (Patwardhan et al., 2014). With the cost of genetic analysis becomes more affordable, species verification has become more rapid and precise through this complementary approach (Ali et al., 2014). 
Owing to its high evolutionary rate, maternal inheritance, lack of recombination, and fast rates of base substitutions, the mitochondrial genome (mtDNA) has been widely used in various aspects of molecular studies, including phylogeography and molecular identification (Caballero et al., 2013; Tran et al., 2015; Gu et al., 2016; Kawamura et al., 2017). Specifically, the mitochondrial gene cytochrome c oxidase subunit 1 (MT-CO1) is acknowledged as the global bio-identification gene for animals (Hebert et al., 2003), and has been extensively used in DNA barcoding. The success of using MT-CO1 gene as an identification marker has been reported in various marine organisms, such as crabs (Ma et al., 2012), fishes (Ward et al., 2005; Hanner et al., 2011; Yi et al., 2017) and bivalves (Ni et al., 2012; Su et al., 2014; Lizano $\&$ Santos, 2014). Thus, although morphological identification is the cornerstone for taxonomic delimitation, genetics has become a necessary complementary tool.

Despite its threatened status, studies on the giant clam in Malaysian waters have been limited in scope and coverage. Past researches in the country have focused mainly on their distributions based on in situ visual observations and morphological identification of specimens (Mohamed-Pauzi et al., 1994; Tan \& Zulfigar, 2003; Montagne et al., 2013). In the waters of Pahang, Terengganu and Johor islands, four species have been reported, namely T. squamosa, T. crocea, T. maxima and Hippopus hippopus (UNEP, 2007). However, H. hippopus was not documented in another study in Tioman island (Pahang) (Tan et al., 1998) and Redang island (Terengganu) (Mohamed-Pauzi et al., 1994). In 2017, Neo et al. reported that H. hippopus was rare and could be found in Johor islands only. Thus, the occurrence and distribution of this species is still contentious. A survey conducted by the Fisheries Department in Redang island found a single individual of $T$. derasa, while T.gigas is extinct when only its fossil was reported (Mohamed-Pauzi et al., 1994). There is little knowledge about the present distributions of the giant clams with limited data on both morphological and molecular approaches in Malaysia.

Based on literature, only two genetic-based studies have been documented in Malaysia; population genetics of $T$. crocea from Tioman island (Waheed, 2016) and genetic variability studies of T. maxima and T. squamosa from Perhentian island (Lim et al., 2018). Both studies were conducted in the east coast of Peninsular Malaysia but with limited geographical coverage. There is no comprehensive data yet on their genetic variability, while species identification of giant clams in Peninsular Malaysian waters have been largely based on morphological data, which should be substantiated with a complementary tool. Therefore, the aim of this study is to update the present occurrence and distribution of endangered giant clams inhabiting the east coast of Peninsular Malaysia through precise identification by applying a DNA barcoding approach.

\section{Materials and Methods}

\section{Sample Collections}

Samples of giant clams were collected during field trips in July, September and October from 2016 to 2019 to groups of islands in three states along the east coast of Peninsular Malaysia; 1. Terengganu islands (northeast), 2. a Pahang island and 3. Johor islands (both southeast) (Figure 1). These groups of islands comprised o Redang and Bidong (Terengganu), Tioman (Pahang), Babi Besar, Pemanggil, Metinggi, Tinggi, Lima Besar and Lima Kechil (Johor) (Table 2). The samples were collected with permits granted by Marine Park Section, Department of Fisheries Malaysia (Prk.ML.6307(45) Jld.4 and JTLM 630-7 Jld. 7 (22)) during scuba diving using non-destructive method.

The samples were identified to species level based on morphological characteristics using the classification keys of Copland and Lucas (1988), and Norton and Jones (1992). Pictures of giant clams were taken on site and labelled to verify identification or for future reference. Specimens varied in size from juveniles to adults 
within the range of $4.0 \mathrm{~cm}$ to $34.8 \mathrm{~cm}$. Mantle tissue clippings of $1 \mathrm{~cm}^{3}$ from 247 samples were placed in $1.5 \mathrm{~mL}$ microcentrifuge tubes in 95 $\%$ ethanol for preservation. Then, all samples were brought back to the Institute of Tropical Aquaculture and Fisheries (AKUATROP) in Universiti Malaysia Terengganu and stored at -4 ${ }^{\circ} \mathrm{C}$ for further genetic studies.

\section{DNA Extraction and PCR Amplification}

DNA from the preserved mantle tissue samples were extracted using the Nucleospin Tissue Kit (Macherey-Nagel, Duren, Germany). A total of $25 \mathrm{mg}$ tissues was cut into small pieces and processed with the kit according to the manufacturer's instructions. Since all samples were morphologically identified as either T. crocea, T. maxima and T. squamosa, primer selection and molecular procedures were based on these species. Sequences of the MT-CO1 gene were PCR-amplified using the MT-CO1 tridacnid-specific primers for T. crocea and T. maxima (forward: LCO: 5'-GGGTGATAATTCG-AACAGAA-3' and reverse: RCO: 5'-TAGTTAAAGCCCCAGCTAAA-3') (Nuryanto et al., 2007) and $T$. squamosa (forward: SQUA-F3: 5'-CATCGTTTAGAGTAATAATTCG-3' and reverse: SQUA-RI: 5'-ATGTATAA ACAAAACAGGATC-3') (Deboer et al., 2008).

PCR amplification was performed in of 25 $\mu L$ of reaction mixture containing approximately $0.50 \mu \mathrm{L}$ DNA template, $0.10 \mu \mathrm{M}$ of forward and reverse primers, $0.50 \mu \mathrm{M} 10 \mathrm{X}$ Easy Taq ${ }^{\circledR}$ Buffer, $0.1 \mu M$ of $2.5 m M d N T P, 1 U$ Easy Taq ${ }^{\circledR}$ $D N A$ polymerase $(500 \mathrm{U} / \mu l)$ (Nanogene, Kuala

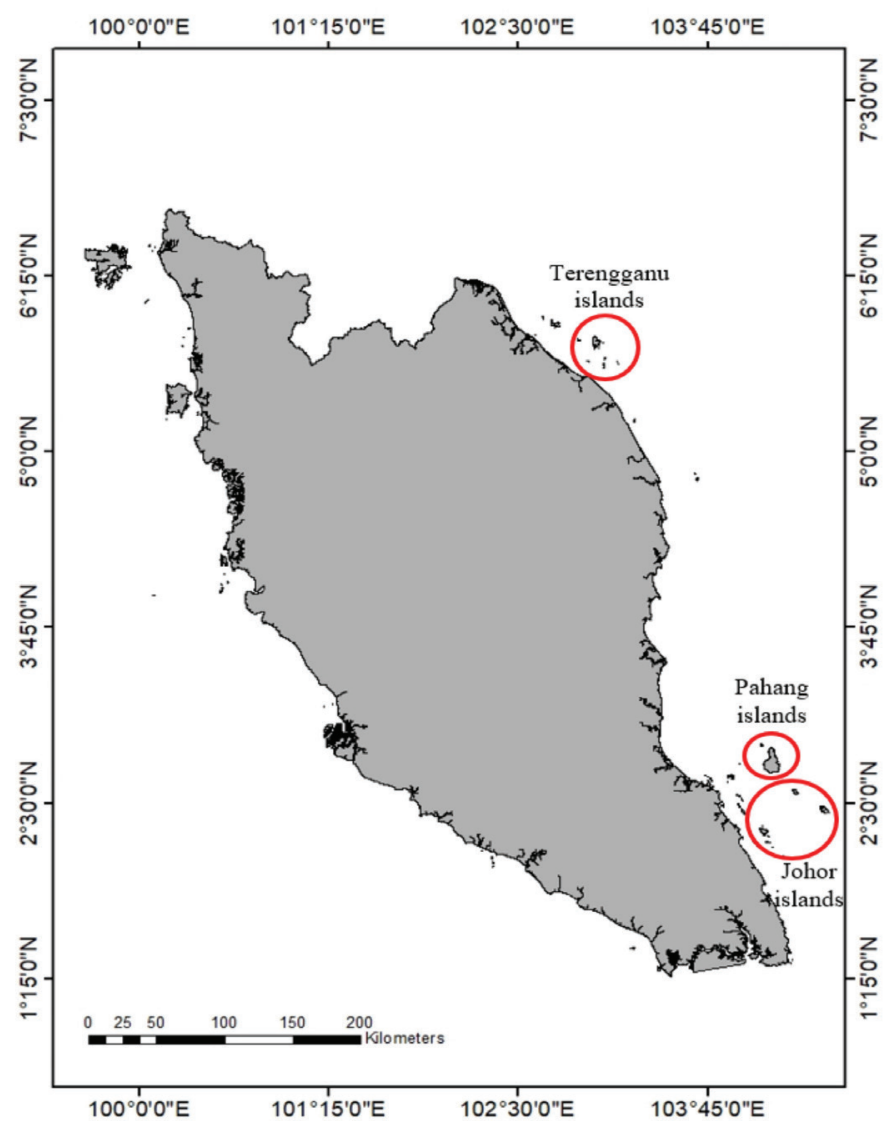

Figure 1: Sampling sites of giant clams in island groups of three states in the east coast of Peninsular Malaysia 
Lumpur, Malaysia) and $18.8 \mu \mathrm{L}$ distilled water (ddH2O). The amplification was carried out in the Master Cycler EP (Eppendorf, Hamburg, Germany). Thermocycling profile for $T$. crocea and T. maxima was set to follow Nuryanto et al. (2007) while T. squamosa was set according to Deboer et al. (2008). Successfully amplified products were sent to a third party (Apical Scientific Sdn Bhd, Kuala Lumpur, Malaysia) for purification and sequencing.

\section{DNA Sequencing and Analysis}

The sequences were aligned using MEGA 7.0 software (Kumar et al., 2016) and the final alignment was screened for stop codons and insertion-deletion mutations, which were absent, to ensure that only the targeted sequences were analysed. Haplotypes were identified using DnaSP software version 5.0.1.1 (Rozas et al.,
2017). The genetic inter-specific and intraspecific distances were estimated in MEGA 7.0 (Kumar et al., 2016) using our haplotype data (Accession No. MT499022 to MT499030) with the outgroup Cerastoderma edule (Accession No. EU523670.1).

Sequence searches were conducted for species identification in online databases, which were the Basic Local Alignment Search Tool (BLAST) of the National Centre of Biotechnology Information (NCBI) (http:// www.ncbi.nlm.nih.gov) and Barcode of Life Data System (BOLD) (www.barcodinglife.org) (Ratnasingham \& Hebert, 2007). Phylogenetic trees were constructed based on two approaches: (1) using current haplotype data of all three putative species and (2) inclusion of representative haplotypes of other giant clam sequences from GenBank (Table 1) to depict the

Table 1: Archived GenBank sequences of MT-CO1 gene included in the study

\begin{tabular}{ccc}
\hline Species & Locality & Accession Numbers \\
\hline Tridacna noae & Australia & KT865882.1 \\
Tridacna noae & Australia & KT865883.1 \\
Tridacna noae & Australia & KT865884.1 \\
Tridacna noae & Australia & KT865885.1 \\
Tridacna gigas & Philippines & KJ202113.1 \\
Tridacna crocea & Indonesia & EU003606.1 \\
Tridacna crocea & Indonesia & EU003607.1 \\
Tridacna crocea & Indonesia & EU003608.1 \\
Tridacna crocea & Philippines & KJ202111.1 \\
Tridacna maxima & Indonesia & EU003613.1 \\
Tridacna maxima & Indonesia & EU346365.1 \\
Tridacna maxima & Indonesia & EU346366.1 \\
Tridacna maxima & Indonesia & EU346367.1 \\
Tridacna derasa & Philippines & KJ202112.1 \\
Tridacna squamosa & Indonesia & EU346362.1 \\
Tridacna squamosa & Indonesia & EU346363.1 \\
Tridacna squamosa & Singapore & JN392020.1 \\
Tridacna squamosa & Singapore & JN392021.1 \\
Hippopus hippopus & Philippines & KJ202105.1 \\
Hippopus hippopus & Philippines & KJ202106.1 \\
Cerastoderma edule & Spain & EU523670.1 \\
\hline
\end{tabular}


relationships within and between populations and species, with $C$. edule as an outgroup. Phylogenetic trees of Neighbor Joining (NJ) and Maximum Likelihood (ML) were constructed using best fit model (Tamura-three-parameter model) with 1,000 bootstrap replicates in MEGA 7.0 software (Kumar et al., 2016) to ensure the robustness of the trees.

\section{Results and Discussion}

\section{Species Identification}

An approximately 467-bp fragment of the MT-CO1 gene was amplified in all specimens. The sequences generated were compared with GenBank BLAST and BOLD archived sequences. This validation step revealed several discrepancies between the morphological and genetic identification. Five morphologically identified $T$. crocea specimens from Terengganu islands (Redang and Bidong) were genetically identified as T. maxima. It should be noted that all of these ambiguous identifications were juvenile individuals. T. squamosa and T. maxima were more widespread, while $T$. crocea appeared to be restricted to the southeastern islands of Pahang and Johor (Table 2).

Levels of inter- and intra-specific divergences in MT-CO1 were estimated in Table 3. No overlap was detected between inter- and intra-specific divergence i.e. presence of a barcode gap was noted. Pairwise genetic distances were according to those expected at different hierarchical levels. I Inter-specific divergence varied from $10.6 \%$ to $16.2 \%$, whereas intra-specific divergence varied from $0.6 \%$ to $0.9 \%$. Inter-generic distance between the outgroup $C$. edule and ingroup members showed values ranging from $37.2 \%$ to $38.5 \%$ (Table 4). T. squamosa and T. crocea were more closely related to each other (0.106) than with $T$. maxima (0.162 and 0.146 , respectively) (Table $3)$.

Table 2: Comparative identification of giant clams based on morphological features and MT-CO1 gene analysis.

\begin{tabular}{|c|c|c|c|c|c|}
\hline \multirow[t]{2}{*}{$\begin{array}{l}\text { Islands } \\
\text { Group }\end{array}$} & \multirow[t]{2}{*}{ Island (N) } & \multicolumn{2}{|c|}{ Species Identification } & \multicolumn{2}{|c|}{$\begin{array}{c}\text { Average Percentage } \\
\text { Similarities }\end{array}$} \\
\hline & & Morphological (N) & MT-CO1 (N) & BLAST & BOLD \\
\hline \multirow[t]{6}{*}{ Terengganu } & \multirow[t]{3}{*}{ Redang (60) } & T. maxima $(41)$ & T. maxima (41) & 99.08 & 98.46 \\
\hline & & T. squamosa (17) & T. squamosa (17) & 97.98 & 99.24 \\
\hline & & T. crocea $(2) \#$ & T. maxima (2) & 99.28 & 98.61 \\
\hline & \multirow[t]{3}{*}{ Bidong (47) } & T. maxima (25) & T. maxima (25) & 99.16 & 98.27 \\
\hline & & T. squamosa (19) & T. squamosa (19) & 97.92 & 99.18 \\
\hline & & T. crocea (3) \# & T. maxima (3) & 99.17 & 97.93 \\
\hline \multirow[t]{3}{*}{ Pahang } & \multirow[t]{3}{*}{ Tioman (46) } & T. crocea $(9)$ & T. crocea $(9)$ & 99.45 & 99.10 \\
\hline & & T. squamosa (14) & T. squamosa (14) & 98.10 & 97.79 \\
\hline & & T. maxima $(23)$ & T. maxima (23) & 99.10 & 99.58 \\
\hline \multirow[t]{7}{*}{ Johor } & Babi Besar (28) & T. crocea (28) & T. crocea (28) & 99.07 & 98.96 \\
\hline & Pemanggil (28) & T. crocea (28) & T. crocea (28) & 99.38 & 99.05 \\
\hline & Tinggi (6) & T. crocea $(6)$ & T. crocea (6) & 99.34 & 99.08 \\
\hline & Metinggi (11) & T. crocea (11) & T. crocea (11) & 99.02 & 99.05 \\
\hline & \multirow{2}{*}{$\begin{array}{c}\text { Lima Besar } \\
\text { (18) }\end{array}$} & T. squamosa (15) & T. squamosa (15) & 98.13 & 98.95 \\
\hline & & T. maxima (3) & T. maxima (3) & 99.28 & 99.44 \\
\hline & Lima Kechil (3) & T. squamosa (3) & T. squamosa (3) & 98.12 & 99.37 \\
\hline
\end{tabular}

*N: No of individuals; \#: Juveniles 
Table 3: Inter- and intra-specific divergence of MT-CO1 sequences using Tamura-3-parameter (T92) with 1,000 bootstrap replications.

\begin{tabular}{ccccc}
\hline & T. crocea & T. maxima & T. squamosa & C. edule \\
\hline T. crocea & $\mathbf{0 . 0 0 9}$ & & & \\
T. maxima & 0.146 & $\mathbf{0 . 0 0 6}$ & & \\
T. squamosa & 0.106 & 0.162 & $\mathbf{0 . 0 0 7}$ & \\
C. edule & 0.372 & 0.385 & 0.385 & $\mathbf{n} / \mathbf{c}$ \\
\hline
\end{tabular}

*Texts in bold indicate intra-specific divergences

The present study successfully verified the taxonomy and distribution of giant clams in the east coast of Peninsular Malaysia using the DNA barcoding technique. The findings indicated that MT-CO1 gene was efficient in species delineation of giant clams as evidenced by the distinct barcoding gap in line with a comprehensive study by Mikkelsen et al., (2007) of marine bivalves, which did not detect overlapping values of inter- and intra-specific divergence. In spite of the intensive sampling, only three species of giant clams were found in the surveyed areas, namely $T$. crocea, $T$. maxima and T. squamosa, although an additional species (H. hippopus) had been previously documented based on morphological characteristics (Neo et al., 2017).
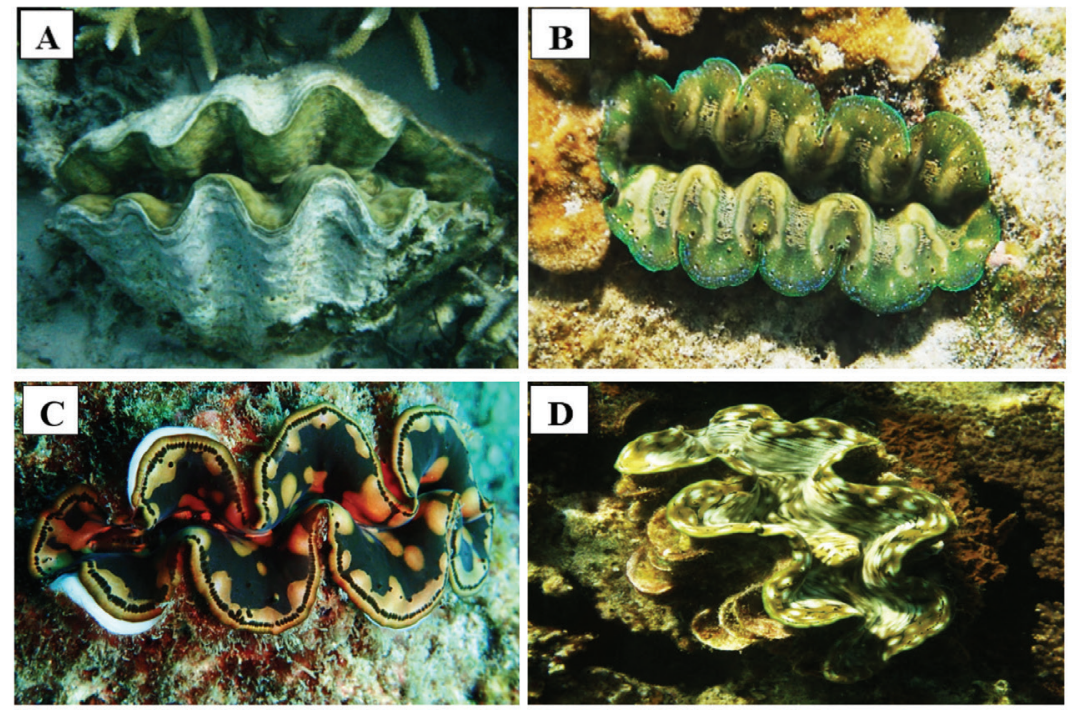

Figure 2: Mantles of giant clam species (A) Hippopus hippopus of Layang-layang Island (Courtesy of Kee Alfian Abdul Adzis), (B) Tridacna crocea from Metinggi island, (C) Tridacna maxima from Bidong island

(Courtesy of Muhammad Haris Hanafi Mohd Habali) and (D) Tridacna squamosa from Bidong island 
Previous studies had noted the rarity of $H$. hippopus, which was only limited to the islands off Johor and in Sabah waters (UNEP, 2007; Neo et al., 2017). However, this study had failed to detect the species in the Johor islands. Since the current study was fairly extensive in its geographical coverage, we believe that the species might be on the verge of local extinction, if not already. It had been reported to be locally extinct in Singapore (Othman et al., 2010).

Furthermore, while Neo et al. (2017) noted a wide occurrence of $T$. crocea in Malaysian waters, our study did not succeed in obtaining the species at Bidong and Redang islands in Terengganu. However, they did not state whether this species was also recorded at the two sites surveyed in the current study. A genetic diversity study of T. maxima and T. squamosa in Perhentian island, Terengganu, also did not make any mention of $T$. crocea (Lim et al., 2018). The author reported an intra-specific genetic variation ranging from $8.1 \%$ to 8.3 $\%$ and inter-specific variation from $12.9 \%$ to $17.2-\%$. The inter-specific variation of 16.2 $\%$ in the current study is concordant with the earlier study, but our intra-specific variation was markedly different. The current study recorded intra-specific variation of $0.6 \%$ to $0.9 \%$, which was consistent with a study on Malaysian oysters (Suzana et al., 2011) and deep-sea clams (Liu and Zhang, 2018), which observed values ranging from $0.1 \%$ to $1.1 \%$ and $0.0 \%$ to 2.66 $\%$, respectively. Intra-specific variation in this present study was also in concordance with a comprehensive study of four marine bivalve genera that recorded an intra-species variation of $0.0 \%$ to $3.2 \%$ (Mikkelsen et al., 2007). Thus, while the giant clam genetic variability was low, there was still some level of variability that should be considered in their management strategies.

Inconsistencies of morphologically identified juveniles, initially presumed to be $T$. crocea specimens, were observed. They were then re-classified as T. maxima based on genetic data. During the juvenile stage, shells of T. maxima were highly similar to $T$. crocea
(Knop, 1996). Thus, it was not surprising that the immature specimens of the former might have been mistaken for the latter. This was in agreement with the study by Waheed (2016), who found presumed $T$. crocea collected from Redang island to be juvenile T. maxima. Both species characteristically embedded into the substrate (Neo et al., 2017). Using phenotypic characters alone could be tricky in identifying the species as the patterns were highly variable due to environmental effects (Colgan et al., 2007).

\section{Phylogenetic Relationships}

The Neighbor-Joining (NJ) and Maximum Likelihood (ML) trees based on 57 unique haplotypes from three species of giant clams based on a Tamura three-parameter model showed similar topology. Each giant clam species formed a monophyletic group with high support as depicted in Figure 3. A re-analysis of combined GenBank reference sequences with other giant clam species yielded similar tree topology in both trees with monophyletic clustering into their own respective groups. Our study showed a close relationship between $T$. squamosa and T. crocea with Tridacna noae, while $T$. maxima was a sister to this cluster. T. derasa was basal to these four species. $H$. hippopus was more closely related to T. gigas than to other Tridacna species analysed (Figure 4).

In parallel with previous research, our study reported the genetic affinity of $T$. squamosa with $T$. crocea compared to T. maxima (Hui et al., 2016; Lizano \& Santos, 2014) although the first pair was well delineated morphologically. However, T. crocea and T. maxima had higher morphological similarities, such as mantle coloration (blue, green and brown) and both were found embedded into the substrate. This characteristic often led to misidentification, particularly in juveniles as observed by Waheed (2016), and similar in this study. Classification of many bivalve groups based on morphology alone (e.g: shell characters) was often very challenging, even among experienced 

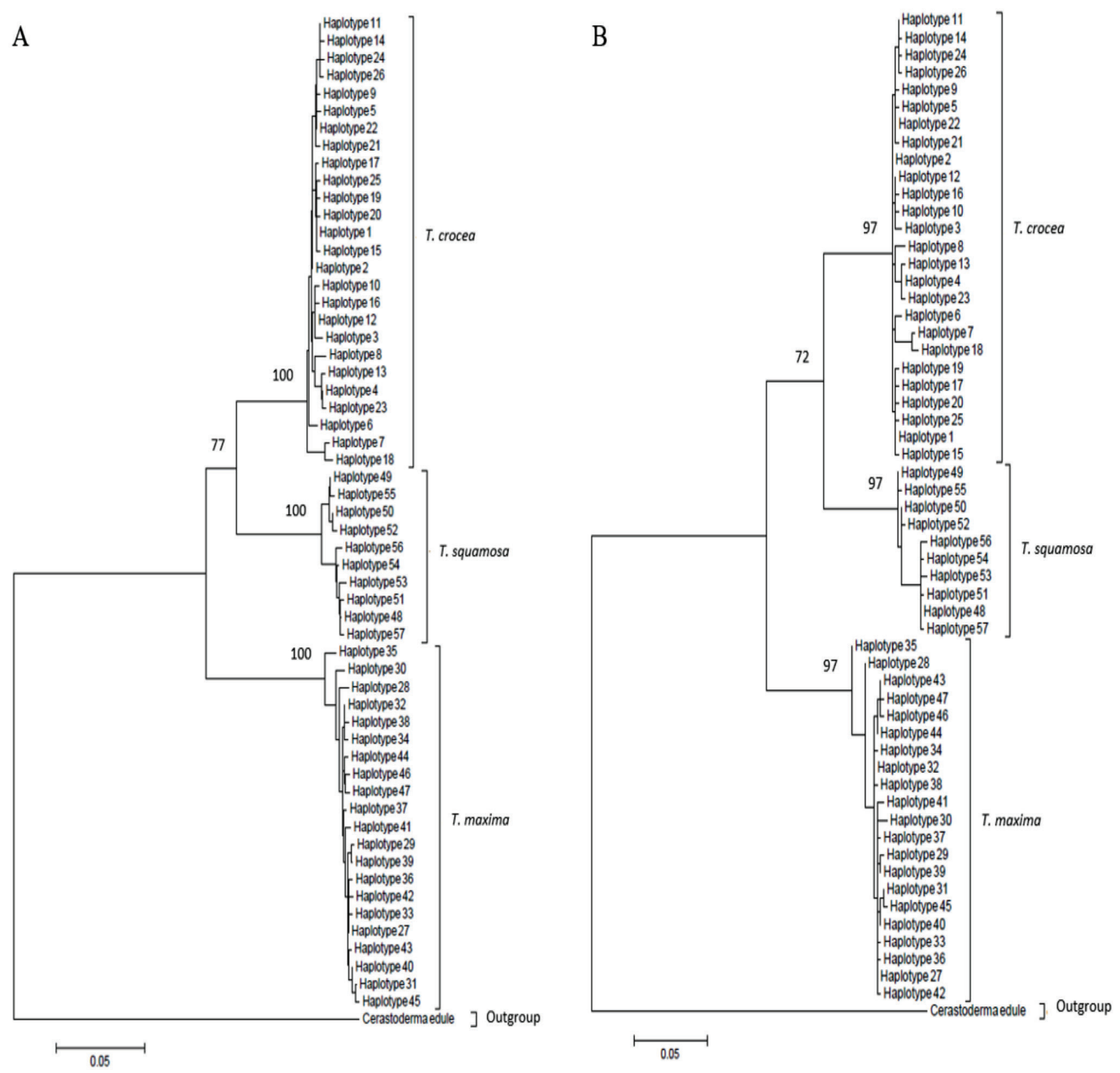

Figure 3: Phylogenetics relationships of three Tridacna spp. from east coast of Peninsular Malaysia based on (A) Neighbour-Joining (B) Maximum Likelihood (Haplotype 1-26 is T. crocea, Haplotype 48-57 is T. squamosa and Haplotype 27-47 is T. maxima)

taxonomists, as highlighted in this case when shells in the juvenile stage of giant clam species closely resembled each other (Knop, 1996). This study affirmed that the application of DNA barcoding in identification of species would enable differentiating species that shared similar morphology during juvenile stages.

\section{Implications to Conservation}

In the past decades, giant clam populations had been over-exploited due to high economic demand as a food source and in the ornamental aquarium trade (Van Wynsberge et al., 2015; Mies et al., 2017). Considering the global declination of giant clam species worldwide, it had become a great urgency to protect and conserve these marine bivalves. This was because giant clams were keystone species that 

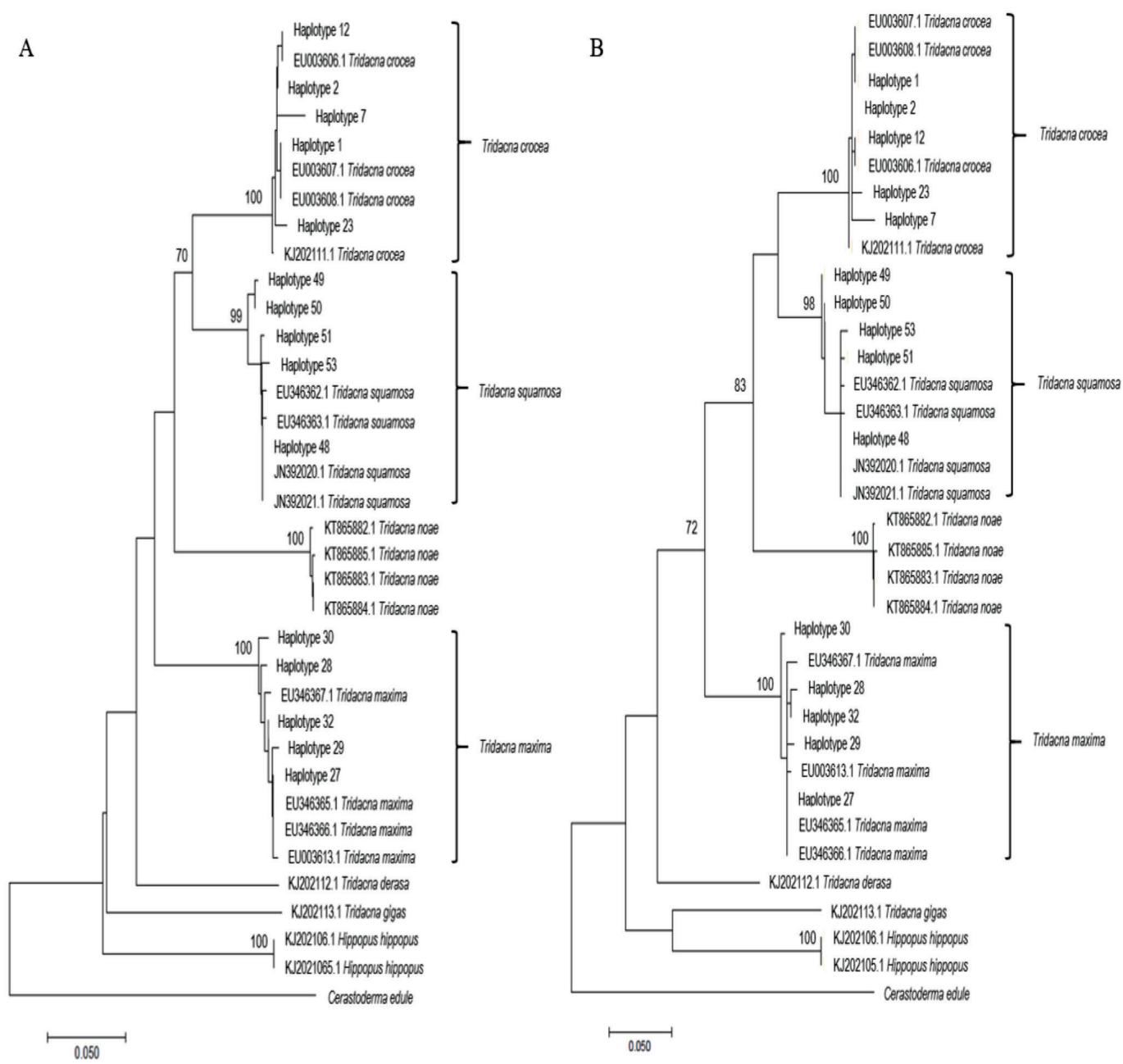

Figure 4: (A) Neighbor-Joining (B) Maximum Likelihood trees of three Tridacna spp. with sequences of other giant clam species from GenBank. Note: Only representative haplotypes of T. crocea, T. maxima and T. squamosa are shown in the tree

played significant roles in coral reef ecosystems (Guibert et al., 2020). Giant clams lived in a symbiotic-mutualism relationship with the microalgae, which allowed both organisms to benefit from each other. Giant clam provided shelter and enough sunlight to zooxanthellae, while the microalgae provided food and energy requirements via photosynthesis (Ikeda et al., 2017; Morishima et al., 2019).

In addition, any excess zooxanthellae algae released from giant clams could be taken up by other zooxanthellate-dependent species, including other marine classes like
Anthozoa, Scyphozoa, Hydrozoa, Gastropoda and Bivalvia. Hence, this could contribute to a balance in the coral reef ecosystem health and biodiversity (Neo et al., 2015; Morishima et al., 2019). Apart from that, the calcium carbonate shells of giant clams also provided substrate for epibiont colonization, increasing the topographic features of coral reefs and act as nurseries for fish (Cabaitan et al., 2008; Neo et al., 2015).

In summary, maintaining healthy populations of giant clams could provide various benefits to coral reef ecosystems in numerous 
underappreciated ways. Therefore, with this knowledge, conservation and rehabilitation of giant clams should be prioritized in future management strategy, and any rehabilitation and restocking programme should take into consideration the distribution of native giant clam species. For example, to avoid disrupting the local ecosystem in Bidong and Redang islands off Terengganu, , T. crocea should not be introduced in those places because they were originally absent in the area.

\section{Conclusions}

Our findings had identified three species of giant clams: T. crocea, T. maxima and T. squamosa inhabiting the east coast of Peninsular Malaysia. $T$. crocea was restricted to the southeastern islands of Pahang and Johor. T. maxima and T. squamosa were found to be omnipresent in all the islands, whereas $H$. hippopus was not recorded in all the surveyed islands. The molecular barcoding approach used in this study had proven to be beneficial in understanding the taxonomic status and distribution of giant clam species in the east coast of Peninsular Malaysia. The output from a DNA barcoding study would be useful for conservation and sustainable management of the giant clams.

\section{Acknowledgements}

The authors would like to express the deepest appreciation to the Education Ministry for funding this study through the Fundamental Research Grant Scheme (Grant No. 59506). Special thanks also to all team members in our connectivity group for their field assistance and to the Institute of Tropical Aquaculture and Fisheries (AKUATROP), UMT, which provided the facilities for this study.

\section{References}

Ali, M.A., Gyulai, G., Hidvégi, N., Kerti, B., Hemaid, F.M.A.A., Pandey, A.K., \& Lee, J. (2014). The changing epitome of species identification - DNA barcoding. Saudi
Journal of Biological Sciences, 21, 204231.

Cabaitan, P.C., Gomez, E.D., Alino, P.M. (2008). Effects of coral transplantation and giant clam restocking on the structure of fish communities on degraded patch reefs. Journal of Experimental Marine Biology and Ecology, 357, 85-98.

Caballero, S., de O. Santos, M. C., Sanches, A., \& Mignucci-Giannoni, A. A. (2013). Initial description of the phylogeography, population structure and genetic diversity of Atlantic spotted dolphins from Brazil and the Caribbean, inferred from analyses of mitochondrial and nuclear DNA. Biochemical Systematics and Ecology, 48, 263-270.

Colgan, D.J., Ponder, W.F., Beacham, E., \& Macaranas, J. (2007). Molecular Phylogenetics of Caenogastropoda (Gastopoda: Mollusca). Molecular Phylogenetics and Evolution, 42, 717-737.

Copland, J.W., \& Lucas, J.S. (1988). Giant clams in Asia and the Pacific. ACIAR Monograph, Brisbane.

Deboer, T.S., Subia, M.D., Erdmann, M.V., Kovitvongsa, K., \& Barber, P.H. (2008). Phylogeography and limited genetic connectivity in the endangered boring giant clam across the coral triangle. Conservation Biology, 22, 1255-1266.

Gu, D. E., Mu, X. D., Xu, M., Luo, D., Wei, H., Li, Y. Y., Zhu, Y. J., Luo, J. R., \& Hu, Y. C. (2016). Identification of wild tilapia species in the main rivers of south China using mitochondrial control region sequence and morphology. Biochemical Systematics and Ecology, 65, 100-107.

Guibert, I., Lecellier, G., Torda, G., Pochon, X., Berteaux-Lecellier, V. (2020). Metabarcoding reveals distinct microbiotypes in the giant clam Tridacna maxima. Microbiome, 8(57), 1-14.

Hanner, R., Floyd, R., Bernard, A., Collette, B.B., \& Shivji, M. (2011). DNA barcoding 
of billfishes. Mitochondrial DNA, 22(1), 27-36.

Hebert, P.D.N., Cywinska, A., Ball, S.L., \& de Waard, J.R. (2003). Biological identifications through DNA barcodes. Proceedings of the Royal Society B: Biological Sciences, 270, 313-322.

Heslinga, G. (2013). SAVING GIANTS: Cultivation and Conservation of Tridacnid Clams. Hawaii: Indo-Pacific Sea Farms.

Hui, M., Kraemer, W.E., Seidel, C., Nuryanto, A., Joshi, A., \& Kochzius, M. (2016). Comparative genetic population structure of three endangered giant clams (Cardiidae: Tridacna species) throughout the IndoWest Pacific: implications for divergence, connectivity and conservation. Journal of Molluscan Studies, 82(3), 403-414.

Ikeda, S., Yamashita, H., Kondo, S-n., Inoue, K., Morishima S-y, Koike, K. (2017). Zooxanthellal genetic varieties in giant clams are partially determined by speciesintrinsic and growth-related characteristics. PLOS ONE, 12(2), 1-14.

Kawamura, K., Miyake, T., Obata, M., Aoki, H., \& Komaru, A. (2017). Population demography and genetic characteristics of the Pacific Oyster Crassostrea gigas in Japan. Biochemical Systematics and Ecology, 70, 211-221.

Knop, D. (1996). Giant Clams: A Comprehensive Guide to the Identification and Care of Tridacnid Clams. Ettlingen: Kraft Druck $\mathrm{GmbH}$.

Kochzius, M., \& Nuryanto, A. (2008). Strong genetic population structure in the boring giant clam, Tridacna crocea, across the Indo-Malay Archipelago: implications related to evolutionary processes and connectivity. Molecular Ecology, 17, 37753787.

Kumar, S., Stecher, G., \& Tamura, K. (2016). MEGA7: Molecular Evolutionary Genetics Analysis Version 7.0 for Bigger Datasets.
Molecular Biology and Evolution, 33(7), 1870-1874.

Lim P.T., Leaw, C.P., Ismail M. N., \& Chan, A.A. (2018). Technical Report: Distribution, Abundance and Population Structure of Two Giant Clam Species (Cardiidae: Bivalvia) of Perhentian Islands Marine Park. Malaysia: Department of Marine Park Malaysia.

Liu, J., \& Zhang, H. (2018). DNA barcoding for species identification in deep-sea clams (Mollusca: Bivalvia: Vesicomyidae), Mitochondrial DNA Part A, 29(8), 11651173.

Lizano, A.M.D., \& Santos, M.D. (2014). Updates on the status of giant clams Tridacna spp. and Hippopus hippopus in the Philippines using mitochondrial $\mathrm{CO} 1$ and $16 \mathrm{~S}$ rRNA genes. Philippine Science Letters, 7(1), 187-200.

Ma, H., Ma, C., \& Ma, L. (2012). Molecular identification of genus Scylla (Decapoda: Portunidae) based on DNA barcoding and polymerase chain reaction. Biochemical Systematics and Ecology, 41, 41-47.

Mies, M., Dor, P., Güth, A.Z., Sumida, Y.G. (2017). Production in Giant Clam Aquaculture: Trends and Challenges. Reviews in Fisheries Science \& Aquaculture, 25(4), 1-12.

Mikkelsen, N.T., Schander, C., \& Willassen, E. (2007). Local Scale DNA barcoding of bivalves (Mollusca): a case study. Zoologica Scripta, 36(5), 455-463.

Mohamed-Pauzi, A., Mohd, Adib, H., Ahmad, A., \& Abdul-Aziz, Y. (1994). A preliminary survey of giant clams in Malaysia. pp 487493 In Mat Isa, M (Ed.), Proceedings of Fisheries Research Conference, 4-6 October 1993, Kuala Terengganu, Malaysia.

Mohammed, T.A.A., Mohamed, M.H., Zamzamy, R.M., \& Mahmoud, M.A.M. (2019). Growth rates of the giant clam Tridacna maxima (Röding, 1798) reared in 
cages in the Egyptian Red Sea. Egyptian Journal of Aquatic Research, 45(1), 67-73.

Montagne, A., Naim, O., Tourrand, C., Pierson, B., \& Menier, D. (2013). Status of coral reef communities on two carbonate platforms (Tun Sakaran Marine Park, East Sabah, Malaysia). Journal of Ecosystems 2013, $1-15$.

Morishima, S-Y., Yamashita, H., O-hara, S., Nakamura, Y., Quek, V.Q., Yamauchi, M., Koike, K. (2019). Study on expelled but viable zooxanthellae from giant clams, with an emphasis on their potential as subsequent symbiont sources. PLoS ONE, 14(7), 1-20.

Neo, M.L., Eckman, W., Vicentuan, K., Teo, S.L-M., Todd, P.A. (2015). Review: The ecological significance of giant clams in coral reef ecosystems. Biological Conservation 181, 111-123.

Neo, M.L., Wabnitz, C.C.C., Braley, R.D., Heslinga, G.A., Fauvelot, C., Van Wynsberge, S., Andréfouët, S., Waters, C., Tan, A.S.H., Gomez, E.D., Costello, M.J., \& Todd, P.A. (2017). Giant Clams (Bivalvia: Cardiidae: Tridacninae): A Comprehensive Update of Species and Their Distribution, Current Threats and Conservation Status. Oceanography and Marine Biology, An Annual Review, 55, 87-388.

Ni, L., Li, Q., Kong, L., Huang, S., \& Li., L. (2012). DNA barcoding and phylogeny in the family Mactridae (Bivalvia: Heterodonta): Evidence for cryptic species. Biochemical Systematics and Ecology, 44, 164-172.

Norton, J. H., \& Jones, G. W. (1992). THE GIANT CLAM: An Anatomy and Histological Atlas. ACIAR Monograph, Brisbane.

Nuryanto, A., Duryadi, D., Soedharma, D., \& Blohm, D. (2007). Molecular Phylogeny of Giant Clams Based on Mitochondrial DNA Cytochrome C Oxidase I Gene. HAYATI Journal of Biosciences, 14(4), 162-166.

Othman, A. S., Goh, G. H. S., \& Todd, P. A. (2010). The Distribution and Status of
Giant Clams (Family: Tridacnidae) - A Short Review. Raffles Bulletin of Zoology, 58(1), 103-111.

Patwardhan, A., Ray, S., \& Roy, A. (2014). Molecular Markers in Phylogenetic Studies-A Review. Journal of Phylogenetics and Evolutionary Biology, 2(2), 1-9.

Ratnasingham, S. \& Hebert, P.D.N. (2007). BOLD: The Barcode of Life Data System (www.barcodinglife.org). Molecular Ecology Notes, 7, 355-364.

Rozas, J., Ferrer-Mata, A., Sánchez-DelBarrio, J.C., Guirao-Rico, S., Librado, P., RamosOnsins, S-E., \& Sánchez-Gracia, A. (2017). DnaSP v6: DNA Sequence Polymorphism Analysis of Large Datasets. Molecular Biology and Evolution, 34, 3299-3302.

Su, Y., Hung, J-H., Kubo, \& Liu, L-L. (2014). Tridacna noae (Röding, 1798) - a valid giant clam species separated from $T$. maxima (Röding, 1798) by morphological and genetic data. Raffles Bulletin of Zoology, 62, 124-135.

Suzana, M., Mohd Lutfi, A., Abdul Hadi, A., Devakie, M. N., \& Siti Azizah, M. N. (2011). Genetic variation in Malaysian oysters: taxonomic ambiguities and evidence of biological invasion. Biological Invasions, 12, 1893-1900.

Tan, S.H., Zulfigar, Y., Salleh, I., \& Yusof, A.A. (1998). Status of Giant Clams in Pulau Tioman, Malaysia. Malayan Nature Journal, 52(3), 205-216.

Tan, S.H. \& Zulfigar, Y. (2003). Status of giant clams in Malaysia. SPC Trochus Information Bulletin, 10, 9-10.

Tran, T.-N., Niu, D.-H., Nguyen, H.-D., Xie, S.M., \& Li, J.-L. (2015). Populations genetic structure of the razor clam Sinonovacula constricta from China, Korea and Vietnam. Biochemical Systematics and Ecology, 61, 429-436.

UNEP (2007). National Reports on Coral Reefs in the Coastal Waters of the South China 
Sea. Thailand: United Nations Environment Programme.

Van Wynsberge, S., Andréfouët, S., GaertnerMazouni, N., Wabnitz, C.C.C., Gilbert, A., Remoissenet, G., Payri, C., Fauvelot, C. (2015). Drivers of density for the exploited giant clam Tridacna maxima: a metaanalysis. Fish and Fisheries, 17(3), 567584.

Waheed, Z. (2016). Patterns of coral species richness and reef connectivity in Malaysia. Netherlands: Leiden University
Ward, R.D., Zemlak, T.S., Innes, T.S., Last, P.R., \& Hebert, P.D.N. (2005). DNA barcoding Australia's fish species. Philosophical Transactions of the Royal Society of London B: Biological Sciences 360(1462), 1847-1857.

Yi, S., Zhong, J., Huang, S., Wang, S., \& Wang, W. (2017). Morphological comparison and DNA barcoding of four closely related species in the genera Misgurnus and Paramisgurnus (Cypriniformes: Cobitidae). Biochemical Systematics and Ecology, 70, 50-59. 